\title{
Mechanisms involved in hearing disorders of thyroid ontogeny: a literature review
}

Caio Leônidas Oliveira de Andrade', Gabriela Carvalho Machado', Luciene da Cruz Fernandes'2, Jamile Morais de Albuquerque ${ }^{2}$, Luciana Lyra Casais-e-Silva ${ }^{3}$, Helton Estrela Ramos ${ }^{4}$, Crésio de Aragão Dantas Alves ${ }^{5}$

\begin{abstract}
Endocochlear, retrocochlear and/or central origin hearing damage may be related to the absence of appropriate levels of thyroid hormone during morphogenesis and/or auditory system development. Hearing disorders related to the thyroid are not well studied, despite speculation on the pathophysiological mechanisms. The objective of this review was to characterize the main pathophysiological mechanisms of congenital hypothyroidism and to evaluate the relationship with central and peripheral hearing disorders. We conducted a literature review using the databases MedLine, LILACS, Cochrane Library, SciELO, Institute for Scientific Information (ISI), Embase, and Science Direct between July and September on 2016. We identified the studies that address hearing disorder mechanisms on the congenital hypothyroidism. Congenital hypothyroidism may have clinical and subclinical manifestations that affect the auditory system and may be a potential risk factor for hearing impairment. Hearing impairment can severely impact quality-of-life, which emphasizes the importance of monitoring and evaluating hearing during the clinical routine of these patients. Arch Endocrinol Metab. 2017;61(5):501-5
\end{abstract}

\section{Keywords}

Thyroid gland; thyroid diseases; congenital hypothyroidism; hearing disorders; hearing loss

\author{
1 Programa de Pós-graduação \\ dos Processos Interativos dos \\ Órgãos e Sistemas (PPgPIOS), \\ Instituto de Ciências da Saúde \\ (ICS), Universidade Federal da \\ Bahia (UFBA), Salvador, BA, Brasil \\ ${ }^{2}$ Departamento de Fonoaudiologia, \\ Instituto de Ciências da Saúde, \\ Universidade Federal da Bahia \\ (UFBA), Salvador, BA, Brasil \\ ${ }^{3}$ Laboratório de Neuroimuno- \\ endocrinologia e Toxinologia, \\ Departamento de Biorregulação, \\ Instituto de Ciências da Saúde \\ (ICS), UFBA, Salvador, BA, Brasil \\ ${ }^{4}$ Departamento de Biorregulação, \\ Instituto de Ciências da Saúde \\ (ICS), UFBA, Salvador, BA, Brasil \\ ${ }^{5}$ Faculdade de Medicina, Unidade \\ de Endocrinologia Pediátrica, \\ Universidade Federal da Bahia \\ (UFBA), Salvador, BA, Brasil
}

Correspondence to: Caio Leônidas Oliveira de Andrade Av. Reitor Miguel Calmon, SN 40110-100 - Salvador, BA, Brasil caioleonidas@gmail.com

Received on Feb/26/2017 Accepted on May/30/2017

DOI: 10.1590/2359-3997000000292

\section{INTRODUCTION}

$\mathrm{T}$ he development of the auditory system depends on the presence of proper levels of thyroid hormone (TH) (1). Several proteins and the synthesis of multiple enzymes require the normal function of the thyroid gland, and hormones are necessary for the structural formation of the middle and inner ear (2) as well as the central auditory system (3). Therefore, it is possible that congenital hypothyroidism may lead to auditory damage with endocochlear origin, retrocochlear origin and/or central parts of the auditory system (3).

The THs play an important role in the morphogenesis, development and maturation of the auditory pathway. Thus, congenital hypothyroidism $(\mathrm{CH})$ can be a potential risk factor for hearing impairment (HI) (4) if the hormones decrease or are absent during the development of the peripheral and central auditory system structures (5).
While the $\mathrm{HI}$ incidence in $\mathrm{CH}$ individuals is currently unknown, studies suggest it may affect $20 \%$ of carriers (5-7). The rate of hearing disorders in $\mathrm{CH}$ patients is approximately 100 -fold higher than the euthyroid population and occurs in approximately 1 per 1000 births (6).

Although the $\mathrm{CH}$ auditory aspects have been investigated in different experimental models involving both in humans and animals, the pathophysiological mechanisms have not been well explored and are not fully elucidated. This lack of information makes it difficult to comprehend all the processes involved in the possible hearing disorders that this disease may cause.

The aim of this literature review was to evaluate the relationships between $\mathrm{CH}$ and both peripheral and central hearing disorders. We focused on the pathophysiological mechanisms involved with these disorders. 


\section{MATERIAL AND METHODS}

\section{Identification and selection of studies}

The literature search was conducted using the following electronic databases: MedLine, LILACS, Cochrane Library, SciELO, Institute for Scientific Information (ISI), Embase, and Science Direct. The databases were consulted between July and September 2016. The databases were mined for literature that specifically focused on pathophysiological processes of congenital hypothyroidism and hearing in human and animal models. The following keywords and descriptors were used during the search and were combined in a number of sequences in English, Portuguese and Spanish languages: hypothyroidism, congenital hypothyroidism, thyroid hormone, thyroid gland, thyroid ontogeny versus auditory hearing maturation, cochlear function, middle olivocochlear system, central auditory processing, hearing loss, and hearing test. The selected studies were chosen based on their title and abstract description. The desired outcomes were structural, physiological, and/or biochemical disorders of the auditory system due to impaired function of the thyroid gland. Papers were excluded from the analysis if they addressed hearing disorders in syndromic cases associated with hypothyroidism or other hypothyroidism conditions that were not caused by abnormalities due to the formation or function of the thyroid gland.

\section{LITERATURE REVIEW}

\section{Congenital hypothyroidism}

$\mathrm{CH}$ is related to defective $\mathrm{TH}$ action due to decreased or absent hormones. $\mathrm{CH}$ is the most common metabolic dysfunction in newborn infants. $\mathrm{CH}$ affects $1: 3000$ to $1: 4000$ births worldwide (8) and $1: 2500$ births in regions of Brazil (9).

$\mathrm{CH}$ etiology is clinically classified as either permanent (80-90\%) or transitory (10-20\%) (10). The causes of $\mathrm{CH}$ are broadly categorized into dyshormonogenesis in $15 \%$ of cases and thyroid dysgenesis (TD) in $85 \%$ of cases (11-14). Dyshormonogenesis is caused by autosomal recessive mutations of key molecules regulating thyroid hormone synthesis, and thyroid hormone production fails in a structurally sound thyroid gland (15). Conversely, TD is caused by a wide range of different structural malformations in the thyroid that result in a wide variety of different $\mathrm{CH}$ phenotypes (16-18). TD is subcategorized into the following classes: 1) thyroid agenesis, which is the most severe form and has a complete lack of thyroid tissue (i.e., both lobes); 2) thyroid hemiagenes, which has one of the thyroid lobes completely missing; 3 ) thyroid hypoplasia, which is characterized as a smaller gland in the normal position; and 4) thyroid ectopia, which involves an abnormal positioning but the gland rests along the migratory path of the primordium. It is known that $5 \%$ of thyroid dysgenesis cases are associated with mutations of the genes responsible for the development of the thyroid follicular cells (e.g., NKX2.1, FOXE1, PAX8, and TSHR) and display a complex pathogeny $(18,19)$.

Untreated $\mathrm{CH}$ can result in a profound impairment of the somatic growth and central nervous system functional differentiation because THs are essential for metabolic development, growth, and homeostasis.

\section{Endocochlear mechanisms of congenital hypothyroidism}

Animal model studies demonstrated that thyroxin $\left(\mathrm{T}_{4}\right)$ plays an important role in the development of embryonic inner ear. In $\mathrm{CH}$ cases with maturation of the sensory epithelium, the inner ear is injured, which suggests there are periods of sensitivity to THs in the developing cochlea (20). In humans the critical time for hearing maturation corresponds approximately to the gap between the embryonic period and the first year of postnatal life (21) (Figure 1).

The cellular function of THs, specifically the active form triiodothyronine $\left(\mathrm{T}_{3}\right)$, is mediated by the thyroid hormone receptor (TR). TR is a binding transcription factor that changes target gene expression (22). The action of $\mathrm{T}_{3}$ on the cochlear sensory cells is partially caused by differential expression of the $\mathrm{TH}$ receptor isoforms receptors present in the developing cochlea: $\alpha($ THR $A)$ and $\beta($ THR $B)(23)$. The expression pattern suggests the cochlea is a direct site of action for THs, which can explain several findings of morphological abnormalities on the spiral organ in hypothyroid rodents $(20,24,25)$.

A delay of THs supply before hearing function development starts results in permanent defects on the cochlea. The deficits of THs can also lead to permanent decreases of the $\beta$-tectorin protein levels in the tectorial membrane, which is associated with tectorial membrane structural abnormalities and cochlear function (26).

The outer hair cells (OHC) are highly sensitive to THs serum levels (26). In cases with low hormone 


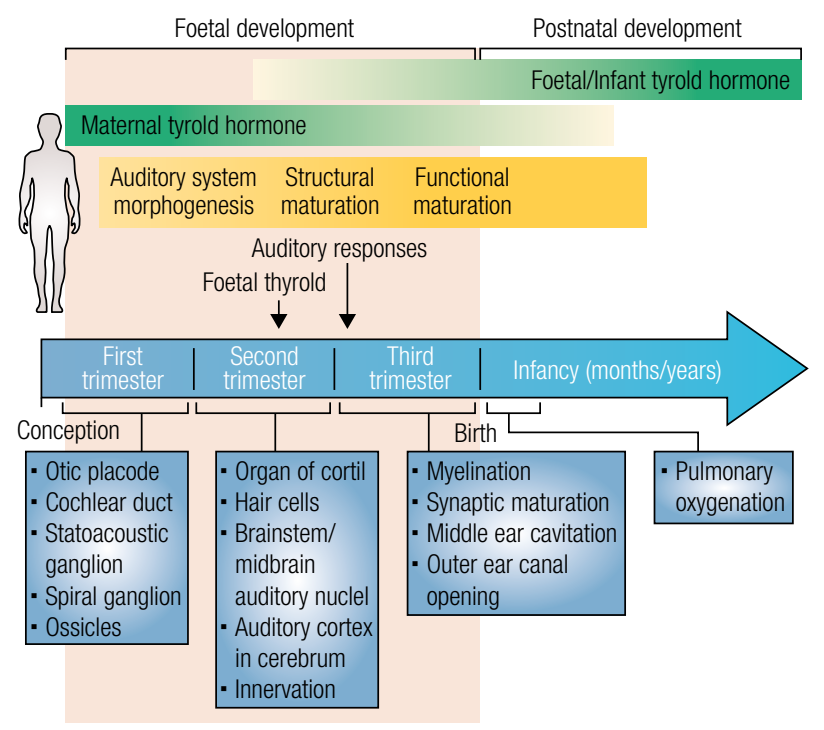

Figure 1. The role of $T_{3}$ in human auditory system formation and development. In the foetal period, the primary auditory responses and the hearing sensitivity progressively matures until early childhood. During the first quarter, the embryo depends totally on the mother's thyroid hormones, which are produced in small amounts during the second half of gestation. After birth occurs, there is an increase in the $T_{4}$ and $T_{3}$ levels in the newborn. Adapted from Ng and cols., 2013 (23).

levels in the beginning of hearing function, the $\mathrm{OHC}$ are poorly differentiated from the other cells in the cochlea. This reduces the number of organelles in the cytoplasm, including ribosomes, endoplasmic reticulum, and mitochondria (27). It is also possible to verify an insufficient formation and changes in microtubule stability with the rise of filamentous actin expression, which increases the stiffness and decreases the cell membrane mass. These changes directly affect the cochlear amplification process (28).

The patients with hypothyroidism show reduced SLC26A4 gene expression. This gene encodes the prestin protein that functions as the motor of the $\mathrm{OHC}$ and regulates the cochlear amplification process (29). The reduction in prestin and decreased amplification decrease its distribution in the OHCs membrane (30). Additionally, the $\mathrm{K}^{+}$channel encoded by $\mathrm{KCNQ}^{4}$ is responsible for endolymphatic potential formation and is also significantly decreased in these conditions (31).

Cumulatively, these factors together with an insufficient opening of the cochlea fluid spaces (inner spiral sulcus, tunnel of Corti, and Nuel's space) affect the development of cochlear micromechanics (32) and damage both the passive and active cochlea mechanisms (33).
There are also descriptions of abnormalities in numerous afferent dendrites and growth delays of the efferent terminals under the OHCs (34). These findings confirm the hypothesis that the absence or decrease of THs can cause harmful effects to the peripheral auditory system and cochlear function.

\section{Retrocochlear/central mechanisms on congenital hypothyroidism}

Previous studies conducted in animal models focused on central nervous system (CNS) development and how the decrease or absence of THs leads to clinical signs suggesting stagnation of normal CNS maturation in $\mathrm{CH}$ cases (34). These findings show an abnormality on the myelination process and subtraction of the axonal projections of the anterior commissure and corpus callosum (35). The abnormalities decrease the pyramidal neurons and cause irregular localization of the corpus callosum neurons. Additionally, there are reduced numbers of microtubules in the neural cytoplasm, changes to the distribution of apical dendrites of the pyramidal neurons (36), and a delay in the cholinergic axons arrival to the hippocampus (37).

Prior studies of the superior auditory pathway have shown reduced levels of the metabolic activity marker deoxyglucose in the following regions: the cochlear nucleus, superior olivary complex, lateral lemniscus nucleus, inferior colliculus, medial geniculate body, and auditory cortex. These data suggest the entire auditory pathway is sensitive to insufficient TH serum levels (38).

A possible explanation for these findings may be associated with the reduced expression of the type 2 deiodinase enzymes, which convert the $\mathrm{T}_{4}$ into $\mathrm{T}_{3}$ hormone in individuals affected by hypothyroidism and reduce the amount of $\mathrm{T}_{3}$ for the auditory centres (39).

Studies of the regions located closer to the spiral organ show changes on the spiral ganglion that cause smaller neurons than found in euthyroid people (40).

The morphology of neurons from the medial olivocochlear tract is altered in $\mathrm{CH}$ cases. However, there are no changes to the neuron population and distribution of this tract. If the neurons do not make proper synaptic contact with the OHC (34), then they can contact other cochlear structures $(27,32)$.

Recent evidence indicates the medial olivocochlear tract innervation is more severely affected in the cases with hypofunctional thyroid glands because it remains at an immature stage compared to lateral olivocochlear tract innervation (34). 


\section{Audiological findings of congenital hypothyroidism}

$\mathrm{CH}$ causes heterogeneity in the disturbances of the auditory structures. Thus, several audiological findings are possible. However, the audiometric disturbances are frequently described as having the following features: sensorineural, bilateral, symmetric, mainly in high frequencies, in a varying degree, and are often mild to moderate severity $(6,7,41-46)$.

Conductive hearing loss and tympanometric abnormalities in addition to acoustic middle ear reflex have also been described in several studies $(5,6,7,41$ 43). However, these conditions are found less frequently and are restricted to cases that are linked to any syndrome.

Once the $\mathrm{TH}$ is essential for auditory nervous system neuromaturation, there is evidence indicating a relationship between the presence of symptoms and central auditory processing disorders in $\mathrm{CH}$ cases (47).

The electroacoustic tests, such as otoacoustics emissions (OAE), responsible for high frequency sensibility and selectivity show varied results. Therefore, it is possible to see an expressive abnormality of the OAE (43), signal amplitude reduction (44), and an increase in the number of ears classified by the equipment as "fail" due to pre-clinical cochlear susceptibility (48).

The tests used to accurately investigate the neurophysiology of the auditory pathway in $\mathrm{CH}$ include the brainstem auditory evoked potentials (BAEP) analysis. The test results show diverse findings, such as prolongation of absolute latency of the I $(42,49)$, III and V (50) waves and increased interpeak interval latency for I-III (50), I-IV (49), and I-V (42). These results suggest there are several alteration sites.

\section{CONCLUSION}

In considering the reviewed content, it has been shown that hypothyroidism, especially in its congenital form, is a potential risk factor for hearing impairment. It can affect hearing from the peripheral structures to central areas that may also lead to inappropriate auditory development. These defects can affect the comprehension and acquisition of acoustic information. Inappropriate auditory development can lead to scholarly, cognitive, language, behavioural and/or social emotional problems. Therefore, it is critical to monitorand evaluate hearing as part of the clinical routine of these patients.

Disclosure: no potential conflict of interest relevant to this article was reported.

\section{REFERENCES}

1. Sohmer $\mathrm{H}$, Freeman S. The importance of thyroid hormone for auditory development in the fetus and neonate. Audiol Neurotol. 1996;1:137-47.

2. Uziel A, Marot M, Rabie A. Corrective effects of thyroxine on cochlear abnormalities induced by congenital hypothyroidism in the rat. II. Electrophysiological study. Brain Res Rev. 1985;351:123-7.

3. Di Lorenzo L, Foggia L, Panza N, Calabrese MR, Motta G,Tranchino $\mathrm{G}$, et al. Auditory brainstem response in thyroid diseases before and after therapy. Horm Res. 1995;43:200-5.

4. Knipper M, Zinn C, Maier H, Praetorius M, Rohbock K, Köpschall I, et al. Thyroid hormone deficiency before the onset of hearing causes irreversible damage to peripheral and central auditory systems. J Neurophysiol. 2000;83:3101-12.

5. Rovet J, Walker W, Bliss B, Buchanan L, Ehrlich R. Long-term sequelae of hearing impairment in congenital hypothyroidism. J Pediatr. 1996;128:776-83.

6. Debruyne F, Vanderschueren-Lodeweyckx M, Bastijns P. Hearing in congenital hypothyroidism. Audiol Res. 1983;22:404-9.

7. François MMD, Bonfils P, Leger J, Czernichow P, Narcy P. Role of congenital hypothyroidism in hearing loss in children. J Pediatr. 1994;424:4444-6.

8. American Academy of Pediatrics; Pediatric Endocrine Society. Congenital Hypothyroidism in Infants, 2016. Available from: <https://www.healthychildren.org/English/health-issues/ conditions/Glands-Growth-Disorders/Pages/Congenital-Hypothyroidism-Infants.aspx>. Access on: Jul 2, 2016.

9. Carvalho TM, Santos HP, Santos IC, Vargas PR, Pedrosa J. Newborn screenings: A national public health programme in Brazil. J Inher Metab Dis. 2007;30:615.

10. Jain V, Agarwal R, Deorari AK, PaulVK. Congenital hypothyroidism. Indian. J Pediatr. 2008;75:363-7.

11. Ramos HE, Nesi-franca S, Maciel RM. New aspects of genetics and molecular mechanisms on thyroid morphogenesis for the understanding of thyroid dysgenesia. Arq Bras Endocrinol Metabol. 2008;52:1403-15.

12. Lafranchi SH. Newborn screening strategies for congenital hypothyroidism: an update. J Inherit. Metab Dis. 2010;33:1-9.

13. Olney RS, Grosse SD, Vogt RF. Prevalence of congenital hypothyroidism--current trends and future directions: workshop summary. Pediatrics. 2010;125(Suppl):31-6.

14. Szinnai G. Clinical genetics of congenital hypothyroidism. Endocr Dev Basel. 2014;26:60-78.

15. Rastogi MV, Lafranchi SH. Congenital hypothyroidism. Orphanet J. Rare Dis. 2010;10:5-17.

16. Fagman $H$, Nilsson M. Morphogenesis of the thyroid gland. Molecular and cellular endocrinology. 2010;323:35-54.

17. Szinnai G. Genetics of normal and abnormal thyroid development in humans. Best Pract Res Clin. Endocrinol Metab. 2014;28:133-50.

18. De Felice M, Di Lauro R. Thyroid development and its disorders: genetics and molecular mechanisms. Endocr Rev. 2004;25:722-46.

19. Chiamolera MI, Wondisford FE. Minireview:Thyrotropin-releasing hormone and the thyroid hormone feedback mechanism. Endocrinology. 2009;150:1091-6.

20. Deol MS. The role of thyroxine in the differentiation of the organ of Corti. Acta Otolaryngol. 1976;81:429-35.

21. Eggermont JJ, Ponton CW, Coupland SG, Winkelaar R. Maturation of the traveling-wave delay in the human cochlea. J Acoust Soc Am. 1991;90:288-98.

22. Sap J, Muñoz A, Damm K, GoldbergY, Ghysdael J, Leutz A, Beug $\mathrm{H}$, et al. The c-erbA protein is a high affinity receptor for thyroid hormone. Nature. 1986;324:635-40.

23. $\mathrm{Ng} \mathrm{L}$, Kelley MW, Forrest D. Making sense with thyroid hormone-the role of T3 in auditory development. Nat Rev Endocrinol. 2013;9:296-307. 
24. Deol MS. An experimental approach to the understanding and treatment of hereditary syndromes with congenital deafness and hypothyroidism. J Med Genet. 1973;10:235-42.

25. Uziel A, Gabrion J, Ohresser M, Legrand C. Effects of hypothyroidism on the structural development of the organ of Corti in the rat. Acta Otolaryngol. 1981;92:469-80.

26. O'Malley BW, Li D, Turner DS. Hearing loss and cochlear abnormalities in. the congenital hypothyroid (hyt/hyt) mouse. Hear Res. 1995;88:181-9.

27. Uziel A, Pujol R, Legrand C, Legrand J. Cochlear synaptogenesis in the hypothyroid rat. Brain Res. 1983;7:295-301.

28. Szarama KB. Thyroid hormone increases fibroblast growth factor receptor expression and disrupts cell mechanics in the developing organ of corti. BMC Dev Biol. 2013;13:1-18.

29. Zheng J, Shen W, He DZZ, Long KB, Madison LD, Dallos P. Prestin is the motor protein of cochlear outer hair cells. Nature. 2000;405:149-55.

30. WeberT, Zimmermann U, Winter H, Mack A, Köpschall I, Rohbock $\mathrm{K}$, et al. Thyroid hormone is a critical determinant for the regulation of the cochlear motor protein prestin. Proc Nat Acad Sci USA. 2002;99:2901-6.

31. Winter $H$, Braig C, Zimmermann U, Geisler HS, Fränzer JT, Weber T, et al. Thyroid hormone receptors TRalpha1 and TRbeta differentially regulate gene expression of Kcnq4 and prestin during final differentiation of outer hair cells. J Cell Sci. 2006;119:2975-84.

32. Cantos R, López DE, Sala ML, Rueda J. Study of the olivocochlear neurons using two different tracers, fast blue and cholera toxin, in hypothyroid rats. Anat Embryol (Berl). 2000;201:245-57.

33. Song L, Mcgee J, Walsh EJ. The influence of thyroid hormone deficiency on the development of cochlear nonlinearities. J Assoc Res Otolaryngol. 2008;9:464-76.

34. Cantos R, López DE, Merchán JA, Rueda J. Olivocochlear efferent innervation of the organ of corti in hypothyroid rats. J Comp Neurol. 2003;459:454-67.

35. Berbel P, Guadaño-Ferraz A, Angulo A, Ramón Cerezo J. Role of thyroid hormones in the maturation of interhemispheric connections in rat. Behav Brain Res. 1994;64:9-14.

36. Berbel $P$, Guadaño-Ferraz A, Martinez M, Quilles JA, Balboa R, Innocenti JM. Organization of auditory callosal connections in hypothyroid adult rats. Eur J Neurosci. 1993;5:1465-78.

37. Rami A, Rabie A. Effects of thyroid deficiency on the development of glia in the hippocampal formation of the rat: an immunocytochemical study. Glia. 1988;1:337-45.

38. Dow-Edwards D, Crane AM, Rosloff B, Kennedy C, Sokoloff L. Local cerebral glucose utilization in the adult cretinous rat. Brain Res. 1986;373:139-45.
39. Guadaño-Ferraz A, Escámez MJ, Rausell E, Bernal J. Expression of type 2 iodothyronine deiodinase in hypothyroid rat brain indicates an important role of thyroid hormone in the development of specific primary sensory neurons. J Neurosci. 1999;19:3430-9.

40. Rueda J. Hypothyroidism impairs the normal development of the size ofspiral ganglion neurons in the rat. 17th Annual meeting of the European Neuroscience Association. 1994;158-91.

41. Crifò S, Lazzari R, Salabé GB, Arnaldi D, Gagliardi M, Maragoni F. A retrospective study of audiological function in a group of congenital hypothyroid patients. Int J Pediatr Otorhinolaryngol. 1980;2:347-55.

42. Bellman SC, Davies A, Fuggle PW, Grant DB, Smith I. Mild impairment of neuro-otological function in early treated congenital hypothyroidism. Arch Dis Child. 1996;74:215-8.

43. Brucker-Davis F, Skarulis MC, Pikus A, Ishizawar D, Matroianni $M A$, Koby $M$, et al. Prevalence and mechanisms of hearing loss in patients with resistance to thyroid hormone. J Clin Endocrinol Metab. 1996;81:2768-72.

44. Santos KTP, Dias NH, Mazeto GMFS, Carvalho LR, Lapate RL, Martins RHG. Audiologic evaluation in patients with acquired hypothyroidism. Braz J Otorhinolaryngol. 2010;76:478-84.

45. Lichtenberger-Geslin L, Santos S, Hassani Y, Ecosse E, Van Den Abbeele T, Léger J. Factors associated with hearing impairment in patients with congenital hypothyroidism treated since the neonatal period: a national population-based 69 study. J Clin Endocrinol Metab. 2013;98:203.

46. Rocco B, Tommaso A, Mariaausilia C, Mariella V, Fortunato L, Filippo De $\mathrm{L}$, et al. Even in the era of congenital hypothyroidism screening mild and subclinical sensorineural hearing loss remains a relatively common complication of severe congenital hypothyroidism. Hear Res. 2015;327:43-7.

47. Andrade $\mathrm{CL}$, Braga $\mathrm{H}$, Fernandes $\mathrm{LC}$, Ramos $\mathrm{HE}$, Alves $C A D$. Resultados da anamnese para rastreio de transtornos do processamento auditivo em crianças com hipotireoidismo congênito. J Med Biol Sci. 2015;14:316-22.

48. Parazzini M, Ravazzani P, Medaglini S, Weber G, Fornara C, Tognola G, et al. Click-evoked otoacoustic emissions recorded from untreated congenital hypothyroid newborns. Hear Res. 2002;166:136-42.

49. Hébert R, Laureau E, Vanasse M, Richard JE, Morissette J, Glorieux $\mathrm{J}$, et al. Auditory brainstem response audiometry in congenitally hypothyroid children under early replacement therapy. Pediatr Res. 1986;20:570-3.

50. Almeida RP, Barbosa JC, Montenegro APDR, Montenegro Júnior RM. Avaliação auditiva de crianças com hipotireoidismo congênito. RBPS. 2009;22:41-7. 